percentage increase in research budget accrues to the Commissariat à l'Energie Atomique (CEA) (18 per cent) while the highest goes to the Commissariat à l'Energie Solaire (COMES) (50 per cent). Nevertheless, CEA has a budget of 5,200 million francs ( $£ 520$ million) and COMES only $\mathbf{3 0 0}$ million francs.

Some of these increases must, however, be qualified by a French budgetary distinction between "crédits de paiement" (money actually received in 1982) and "crédits d'autorisation" (money which can be committed, as in ordering a piece of equipment, but not necessarily spent).

It is in terms of these crédits d'autorisation that there will be an increase of 29 per cent (to 25,000 million francs from 19,000 million francs). In crédits de paiement, the increase is only 15 per cent. Thus in his budget Chevènement is gambling heavily - as is all of France - on future economic success. Of what he offers to research, about half is not yet in the government's coffers. Robert Walgate

\section{UK research funding}

\section{Cutting problems}

The British Science and Engineering Research Council is alarmed that the quality of research in some outstanding science departments is being jeopardized by the reluctance of universities to be sufficiently selective in deciding where to make economies. The council's anxiety has apparently increased since the University Grants Committee informed individual universities last July of the cut in their incomes and student numbers over the next three years. Although guidance on student quotas for different subject areas was fairly specific, the council considers that advice on where to save money was too vague. It is disturbed by evidence that universities are tending to make unselective cuts.

The worry is that universities are endangering the concept of a well-found laboratory on which the dual support system for funding university research depends. The system demands that universities provide well-equipped laboratories run by tenured staff while the research councils award grants to individuals for specific research projects. The Science and Engineering Research Council intends to continue awarding grants on the merit of proposals provided that they come from laboratories with an adequate research base. But it says that if universities make cuts across the board, facilities in many departments may be so weakened that it would be unable to support their work.

That apparently has already happened on occasion in recent years. In such cases, the council has made grants conditional on the university providing the funds for basic equipment. By March 1980, the position was such that the Advisory Board for the Research Councils set up a committee to recommend what should be done. The committee has now resumed its investigations after postponing its report when the latest cuts to the universities became known.

Sir Alec Merrison, chairman of the committee, believes that it should report by the end of the year so as to provide universities with guidance on how to reorganize while minimizing the damage to research.

Judy Redfearn

\section{US engineering graduates Firms step in}

\section{Washington}

Increasingly concerned at growing bottlenecks in the production of engineers by US universities and colleges, as well as the decreasing willingness of the federal government to provide financial assistance to overcome this problem, private companies are taking matters into their own hands.

Two weeks ago, member companies of the American Electronics Association, computer and data processing equipment manufacturers who have been among the hardest hit by current shortages in qualified manpower, agreed that over the next five years they would set aside two per cent of their research and development budget to assist university and college computer science and engineering departments.

This decision could produce an extra $\$ 50$ million to help support engineering education, and follows the announcement in September that the Exxon Education Foundation is to launch a five-year, $\$ 15$-million programme of assistance to engineering schools and faculty members across the country. The money will be shared among 66 colleges, including both private and state universities. Under the programme, 100 doctoral candidates will receive an average of $\$ 50,000$ over the three years of their studies. An additional $\$ 20,000$ will be provided to 100 departments of engineering, earth sciences and computer science specifically to help subsidize higher salaries for young teaching faculty members .

Although the Exxon Foundation's grant programme is said to be the largest ever undertaken by a corporate entity, it is not unique. IBM, for example, has awarded 278 graduate and predoctoral fellowships in mathematics, science and engineering in the past three years, and is making 180 grants of $\$ 25,000$ each to university departments between 1980 and 1984 - a total of $\$ 4.5$ million.

Furthermore, the private sector is so concerned that efforts to revitalize the US technological base could founder on a shortage of adequately trained engineers that Exxon and IBM have joined with six other major corporations (AT\&T, du Pont, General Electric, General Motors, General Telephone and Electronics and Union Carbide) to sponsor a two-year programme in Washington under the umbrella of the American Society for Engineering Education to consider how the federal government might help to solve the shortage of engineering college faculty.

Although pay differentials are the most widely-quoted cause for the current shortage, other factors from federal regulation of research to the obsolesence of teaching equipment - have contributed to the crisis.

There is no shortage of potential students. News of the heavy demands for engineering graduates, often being offered starting salaries of $\$ 25,000$ a year or more, has filtered quickly down into the schools, and some universities and colleges say that they are now having to limit the intake of engineering undergraduates.

According to figures being prepared by the National Science Foundation, however, private industry employers are now having "major difficulties" in filling their requirements for computer, electrical/electronic and chemical engineers. Employers had reported "some difficulties" in recruiting mechanical, industrial, petroleum and mining engineers, but said that demand and supply were in balance for aerospace engineers, while there was evidence of an oversupply of civil engineers.

Nor is it only the private sector that is worried. General Robert T. Marsh, commander of the US Air Force Systems Command is concerned that a shortage of highly qualified scientists and engineers is threatening the US defence capability.

The Reagan Administration has already advertised its concern for the general shortage of engineering graduates in both the private and military sectors. It insists that this problem should, where possible, be solved through the maximum involvement of private companies.

Some of these efforts, however, may already be beginning to backfire. Dr Ivan Bennett, dean of New York University Medical Center, has told the advisory committee to the director of the National Institutes of Health that although recent changes in the tax law make it more attractive for companies to donate secondhand research equipment to universities, some corporate leaders had told him that the value of this incentive was virtually cancelled out by the accelerated depreciation now allowed on such equipment. David Dickson

\section{Genetic engineering Biogen digs in}

\section{Zurich}

Within a period of days Biogen, one of the first biotechnology companies, has opened an American counterpart to its Geneva laboratory, appointed one of last year's Nobel prizewinners as chairman of its board of directors and secured $\$ 20$ million of additional financial backing. Biogen seems bent on being among the ten 